Available online: https://journals.researchsynergypress.com/index.php/ijebce/

International Journal of Entrepreneurship, Business and Creative Economy (IJEBCE)

ISSN 2775-3085 (Online) | 2775-3107 (Print)

Volume 1 Number 1 (2021): 1-12

\title{
Entrepreneurial Intention Among the University Students: Personality Traits that Matter
}

\author{
Cheah Chew Sze', Yeow Jian Ai', Yeo Sook Fern'1, Yeap Jomay ${ }^{1}$ \\ ${ }^{1}$ Faculty of Business, Multimedia University, Melaka, Malaysia
}

\begin{abstract}
Within this research, we want to study if personality traits will be the significant predictors for entrepreneurial intention. Based on our literature surveys, which showed that personality traits are found significantly linked to entrepreneurial intention in developed countries, we want to focus on four personality traits: (1). self-efficacy, (2). needs for achievement, (3). locus of control, and (4). tolerance for risk. We collected the data from total of 200 university students in Malaysia through a self-administered questionnaire, and later analyzed using SEM PLS 3.0. We found that self-efficacy, locus of control, and tolerance for risk are indeed significant predictors, even though the need for achievement is not. Comparatively, a small sample size may lead to generalization issues, self-report bias, and cross-sectional design considered the main limitations of this study. We also revealed that tolerance for risk is the most influential factor in the entrepreneurial intention among university students. Thus, our finding contributes to the scholarly literature on entrepreneurship study in Malaysia and provides some recommendation for universities to encourage and support entrepreneurship among students.
\end{abstract}

Keywords: Entrepreneurial intention; Self-efficacy; Locus of control; Tolerance for risk; Personality traits

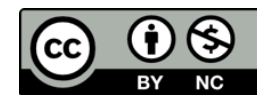

This is an open access article under the CC-BY-NC license.

\section{INTRODUCTION}

Entrepreneurship plays an important role in a healthy economy and critical for sustaining economic prosperity as they create employments, producing innovations, and increasing the productivity growth of an economy (Kritikos, 2014; Riswanto, 2016, August). According to the Department of Statistics Malaysia [DOSM] (2020), the unemployment rate in Malaysia has increased from 3.3\% to 5.3\% from the year 2019 to the year 2020. Despite the effect of the COVID 19 pandemic, the unemployment rate still marks an increasing trend, especially among fresh graduates. One way to solve this issue, is to promote entrepreneurship. Musa \& Semasinghe (2013) concluded that unemployment has a significant link with entrepreneurship; some countries with more entrepreneurs have a low rate of unemployment. Inspired by this result to increase the boost Malaysia's GDP and reduce the unemployment rate, the Government of Malaysia has implemented the Apprenticeship Scheme to reduce the unemployment rate among the young (The Malaysian Times, 2015). This Apprenticeship Scheme is targeting "Penilaian Menengah Rendah" (PMR)/Lower Secondary Assessment and "Sijil Pelajaran Malaysia" (SPM)/Malaysian Certificate of 
International Journal of Entrepreneurship, Business and Creative Economy (IJEBCE), Vol. 1 (1), 1-12 Entrepreneurial Intention Among the University Students: Personality Traits that Matter Cheah Chew Sze, Yeow Jian Ai, Yeo Sook Fern, Yeap Jomay

Education leavers and school dropouts. Furthermore, the training programs that are under this Apprenticeship scheme is fully funded by the Human Resource Development Fund (HRDF), which mainly consists of theoretical and practical skill-based courses like Mechatronics and Plastics Injection Moulding at approved training centers.

\section{LITERATURE REVIEW}

\section{Young Entrepreneur}

An entrepreneur is the owner of a business who tries to make profits despite the risks that are going to be faced by them. A July 2015 report on youth entrepreneurship shows that there are younger individuals who would like to start their own business 1.6 times more than the older generation as according to Global Entrepreneurship Monitor (GEM). As stated by Global Entrepreneurship Monitor (GEM) (n.d), GEM categorized youth entrepreneurs as entrepreneurs adult aged from 18 to 34. Chigunta (2002) defined youth entrepreneurs as the practical application of enterprising qualities, such as innovation, creativity, initiative, and risk-taking into the work environment (either self-employed or being employed in a small start-up firm), using the appropriate skills necessary for success in that environment and culture. Youth entrepreneurship is important in Malaysia because it creates employment opportunities, and it will reduce the unemployment rate in Malaysia. Next, youth entrepreneurship promotes innovation within the youngster; this will eventually help youth in developing new skills and experiences that can be used to many other challenges in their lives. In formulating what matter most in youth entreprenurship intention, mostly we will lean on Learned Needs Theory, and Social Cognitive Theory.

\section{Learned Needs Theory}

In the year 1961, David McClelland has established a book namely "The Achieving Society". He identified three motivating drivers that he believed that everybody has. The three motivating drivers are a need for affiliation, a need for power, and a need for achievement. This theory is named as Human Motivation Theory or Learned Needs Theory. McClelland (1961) showed that these motivating drivers are learned from time to time. We believe that these threemotivating drivers will be our dominant motivators regardless of our culture, age, gender, or ethnicity. Further, McClelland (1961) believed that achievement- motivated individuals are those who will produce a good result.

\section{Social Cognitive Theory}

According to Nevid (2012), Social Cognitive Theory proposed that an individual does not simply react to environmental influence, but they would search and interpret the information that they find. According to Bandura (2005), Social Cognitive Theory is like a change agent, development agent, and adaptation agent. He furthermore explained that a change agent is someone who purposely influences someone's functioning. Next, Albert Bandura has developed Self-Efficacy as part of a larger theory in Social Learning Theory (Ashford \& Lecroy, 2010). The Social Cognitive Theory is made up of four approaches of goal realization, namely self-efficacy, self-evaluation, selfobservation, and self-reaction. All these elements are interrelated; all of them will have an effect on influencing motivation and achieving goals. According to Lunenburg (2011), self-efficacy can directly influence the learning ability of a person, their performance, and their motivation, because 
International Journal of Entrepreneurship, Business and Creative Economy (IJEBCE), Vol. 1 (1), 1-12 Entrepreneurial Intention Among the University Students: Personality Traits that Matter Cheah Chew Sze, Yeow Jian Ai, Yeo Sook Fern, Yeap Jomay

people will only try to learn those things that they believe they will be successful in. Based on Bandura's Social Cognitive Theory, Rotter (2004) had expanded Bandura's idea, and he had created the term "Locus of Control". Locus of control is meant by how individuals view their relationship in relation to the environment. Self-efficacy involves a person's belief in their own abilities, while locus of control refers to the belief that the power a person has over their lives.

\section{Entrepreneurial Intention}

Entrepreneurial intention is the decision made to venture into a new business, and whereby this intention is considered as the main element (Guerrero, Rialp \& Urbano, 2008; Nabi, Holden \& Walmsley, 2006). Gatewood, Shaver, and Gartner (1995) had mentioned that this intention is linked with feasibility and desirability, whereby Harris and Gibson (2008); Hisrich and Peters (2004) stated that entrepreneurial intention is caused by many factors. Based on several studies, there have been two lines of research that have been conducted to find out the factors influencing entrepreneurial intention. The first line of research is regarding cognitive or personal factors, and the second line of research is about behavioral factors. McClelland (1965) and Brockhaus (1980) had analyzed that regarding cognitive factors, they found out about a particular set of personality traits and motives which differentiate them from the others. Mitton (1989) stated that entrepreneurs as individuals that have certain psychological characteristics, for example, a need for control, commitment to their work, and they like challenges. Koh (1996) supported Mitton's: that some psychological traits are only notable to entrepreneurs. The importance of studying the entrepreneurial intention among the undergraduates is to allow us to get a better understanding of whether they will take the initiative to start a new business or not (Gilmartin et al., 2019).

\section{Self-efficacy}

According to Bandura (1997), he suggested that self-efficacy is people who believe that they have the ability to perform. Self-efficacy can also be referred to as a belief that one can perform a certain set of jobs with the help of the behavior required (Bandura, 1997). People with high self-efficacy will usually think and act differently compared to people with low self-efficacy (Zulkosky, 2009). People with high self- efficacy recover quickly from failure, they learn from their mistakes, and they are usually people who excel in their tasks performed (Bandura, 2010). According to Lunenburg (2011), self-efficacy can directly influence the learning ability of a person, their performance, and their motivation, because people will only try to learn those things that they believe they will be successful in. An individual with high self-efficacy will influence them in making the decision to be engaged in entrepreneurial action. Self-efficacy will affect an individual's intention in realizing their success in personal objectives (Cromie, 2000). Furthermore, researches have proved that selfefficacy is positively related to entrepreneurial intentions (Farrukh, Khan, Khan, Ramzani \& Soladoye, 2017; Karlsson \& Moberg, 2013; Santos \& Liguori, 2020; Rosique-Blasco, MadridGuijarro, \& García-Pérez-de-Lema, 2018).

\section{Need for Achievement}

According to McClelland (1961), a person's behavior is consists of the need for achievement; this need regulates a person's action over the long term. Besides that, McClelland (1961) had explained that the need for achievement is meant by a person who has a desire to be able to succeed in 
International Journal of Entrepreneurship, Business and Creative Economy (IJEBCE), Vol. 1 (1), 1-12 Entrepreneurial Intention Among the University Students: Personality Traits that Matter Cheah Chew Sze, Yeow Jian Ai, Yeo Sook Fern, Yeap Jomay

achieving something, and thus this need will influence a person in becoming an entrepreneur. Next, a person with a higher need for achievement is said to enjoy solving problems alone, enjoy risk taking, and appreciates individual responsibility. At the same time, Zeffane (2013) has said that a person who has a high need for achievement has the capability to cope with more challenging entrepreneurial activity. Also, Nathawat, Singh, and Singh (1997) had pointed out that a person with a low need for achievement is directly related to low expectations; low performance and the failure. Thus, an individual with the need for achievement could be a good entrepreneur candidate (McClelland, 1961). As such, university students that have a high need for achievement will lead to a high level of entrepreneurial intention (Karabulut, 2016; Maharani, Indrawati \& Saraswati, 2020; Nasip, Amirul, Sondoh Jr, \& Tanakinjal, 2017; Yukongdi \& Lopa, 2017).

\section{Locus of Control}

The locus of control is divided into two, namely, internal locus of control and external locus of control. People with an internal locus of control believe that they have full control of their life, whereby their actions are dependent on their own personality. On the other hand, a person with an external locus of control is whereby a person's behavior depends on the action of another person or their own fate, whereby their life is way beyond the person's ability to control. According to Rotter (1966), the internal locus of control is more related to learning, and this will directly support and motivates a person actively; in contradiction, the external locus of control encourages passivity. It has been proven that a person with a higher internal locus of control is more suitable to be an entrepreneur as compared to those who have a lower internal locus of control (Diaz, 2003; Rotter 1966). Besides that, Prakash, Jain, and Chauhan (2015) reiterated that a person with an internal locus of control would increase the entrepreneurial intention. Internal locus of control refers to the ability to control own life, and external locus of control refers to an attitude that is depending on fate or luck. Internal control is usually related to entrepreneurial intention. Internal locus of control is an important factor in influencing entrepreneurial intention in various studies (Asante \& AffumOsei, 2019; Hsiung, 2018; Tentama \& Abdussalam, 2020).

\section{Tolerance of Risk}

Gürol and Atsan (2006) had said that entrepreneurship is always associated with risk-taking. Risktaking is meant by a person's orientation towards taking uncertain chances in a decision-making situation (Sexton \& Bowman, 1985). The propensity to take risk is related to the probability of activity having less than 100 percent success (Van der Kuip \& Verheul, 2003). Furthermore, Kazmi, Uddin, and Nabradi (2017) had also found out that entrepreneurs had more risk-taking characteristics as compared to non- entrepreneurs. According to Koudstaal, Sloof, and Van Praag (2016); Thomas \& Mueller (2000), entrepreneurs would rather face risks in their business rather than being involved in an uncertain situation. Previous studies had shown that entrepreneurship is related to risk-taking (Gurol \& Atsan, 2006), and entrepreneurs are usually risk-takers (Jaafar, Abdul-Aziz \& Ali, 2009; Kozubíková, Dvorský, Cepel \& Balcerzak, 2017; Salleh \& Ibrahim, 2011; Sexton \& Bowman 1985).

Based on our discussion, henceforth we develop our theoretical framework, shown in Figure 1. Our Hypotheses are: 
International Journal of Entrepreneurship, Business and Creative Economy (IJEBCE), Vol. 1 (1), 1-12 Entrepreneurial Intention Among the University Students: Personality Traits that Matter Cheah Chew Sze, Yeow Jian Ai, Yeo Sook Fern, Yeap Jomay

H1: Self-efficacy is significantly influence the university student's entrepreneurial intention H2: Need for achievement is significantly influence university student's entrepreneurial intention H3: Locus of control is significantly influence university student's entrepreneurial intention $\mathrm{H} 4$ : Tolerance of risk is significantly influence university student's entrepreneurial intention

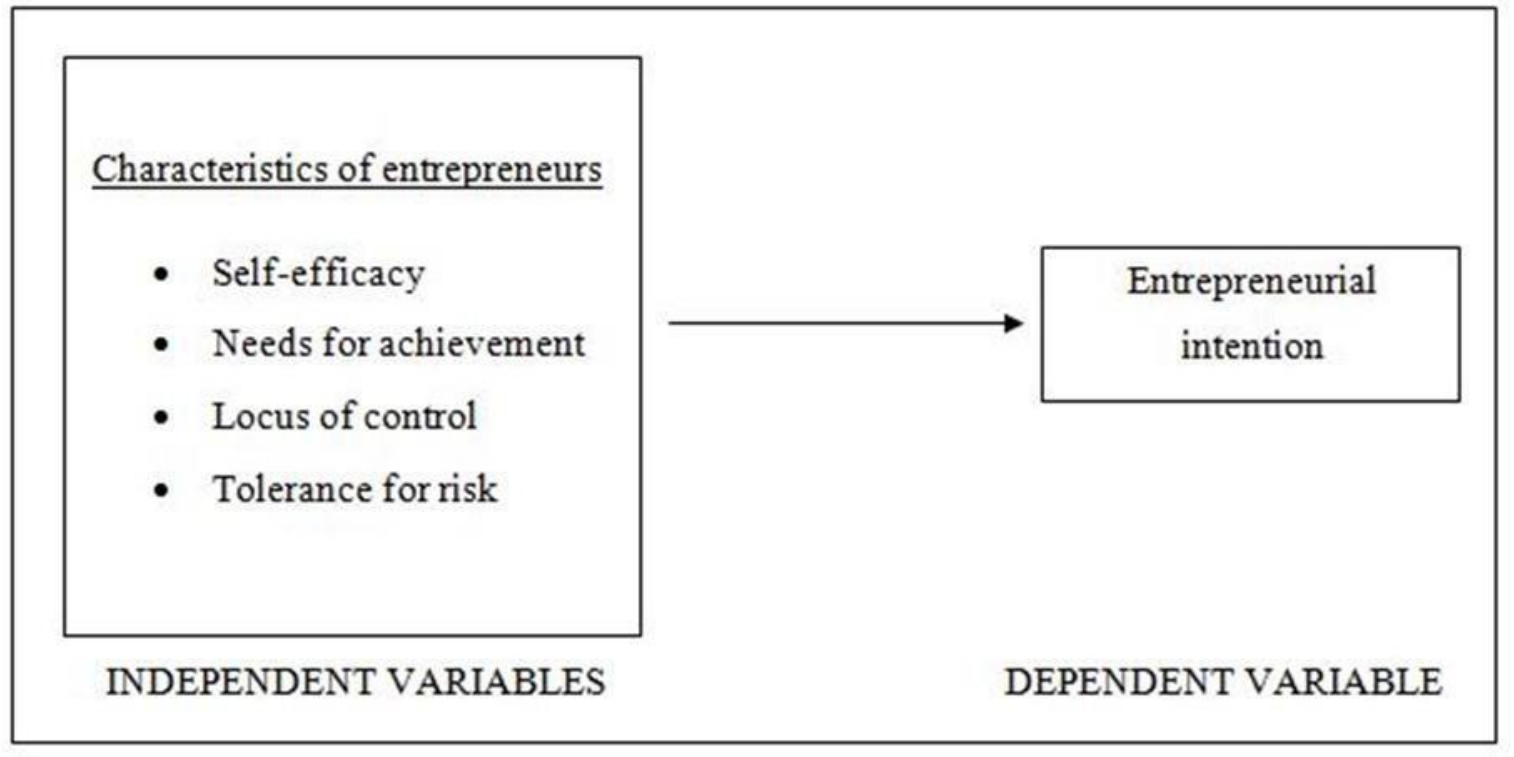

Figure 1: Proposed model

\section{RESEARCH METHOD}

The population of the study is full-time undergraduate final year university students in Malaysia, with 200 chosen as sample size. The reason why final year students were chosen for this research is that this group of students was graduating and stepping into the workforce soon. Therefore, they have some important decisions to make, such as whether choosing to be selfemployed or being employed by others. The sampling method chosen for this study is the nonprobability sampling method, which is convenience sampling. Convenience sampling was employed in this study because the target populations are homogeneous and it is also a more affordable, easy way to reach the ready respondents (Etikan, Musa \& Alkassim, 2016). A total of 250 questionnaires were distributed, only 200 were able to collect back and complete, yielding an $80 \%$ response rate.

The data obtained were analyzed using the Social Sciences Statistical Package (SPSS) program and proceeded by using the Partial Least Square method to test the hypotheses generated using the Smart PLS 3.0 software. PLS-SEM was adopted in this study mainly to meet the research objective for prediction and explain the relationship between exogenous and endogenous constructs (Hair et al., 2017).

A two-stage approach involving the estimation model and the structural model has been implemented. In addition, the bootstrapping approach with the 5000 resamples was used to assess the validity of the loading and path coefficients of the constructs (Hair et al., 2017). A total of 25 validated measurement items or indicators for the constructs were adopted from previous studies (Wilson, Kickul, Marlino, 2007; David, 2009). The rule of thumb is that the load for the indicator 
International Journal of Entrepreneurship, Business and Creative Economy (IJEBCE), Vol. 1 (1), 1-12 Entrepreneurial Intention Among the University Students: Personality Traits that Matter Cheah Chew Sze, Yeow Jian Ai, Yeo Sook Fern, Yeap Jomay

must be more than 0.5 to guarantee the reliability of the indicator, as indicated by Hair et al. (2017). As a result, items with poor loadings, such as Self Efficacy (SE5) loading less than 0.5, have been removed.

\section{FINDINGS AND DISCUSSION}

\section{Respondents Profile}

Out of 200 respondents, 93 of them are Chinese and scored the highest percentage of $46.5 \%$, followed by Indians (27\%) and Malays (26.5\%). A clear majority of them at their age of 20 to 23 , and 54 percent of them from faculty business or management. The majority of the students $(61 \%)$ in this study were not actively involved in the university's clubs, sports, and other activities.

\section{Measurement Model Assessment}

In order to investigate the convergent validity, Hair et al. (2014) indicated that the average variance extracted (AVE), which is the mean-variance extracted for building loading items, were all above the recommended value of 0.5 or higher (Hair et al., 2017). All AVE values for this sample were higher than the threshold value of 0.5 from 0.516 to 0.735 , as seen in Table 1 . In sum, for all contracts, the convergent validity was met. All the composite reliability values ranging from 0.841 to 0.932 surpass the cut off value of 0.6 (Bagozzi \& Yi, 1988), as can be seen in Table 1. As such, it can be concluded that all measurements are reliable on the basis of composite reliability.

Table 1: Results of the measurement model

\begin{tabular}{|c|c|c|c|c|}
\hline Construct & Items & Loadings & $A V E$ & $C R$ \\
\hline Entrepreneurial Intention & $\begin{array}{l}\text { EI1 } \\
\text { EI2 } \\
\text { EI3 } \\
\text { EI4 } \\
\text { EI5 }\end{array}$ & $\begin{array}{l}0.905 \\
0.804 \\
0.748 \\
0.885 \\
0.932\end{array}$ & 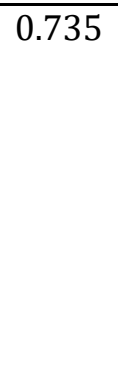 & 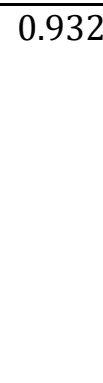 \\
\hline Self Efficacy & $\begin{array}{l}\text { SE1 } \\
\text { SE2 } \\
\text { SE3 } \\
\text { SE4 } \\
\text { SE5 }\end{array}$ & $\begin{array}{c}0.878 \\
0.880 \\
0.800 \\
0.785 \\
\text { Deleted }\end{array}$ & 0.700 & 0.903 \\
\hline Need for Achievement & $\begin{array}{l}\text { nAch1 } \\
\text { nAch2 }\end{array}$ & $\begin{array}{l}0.687 \\
0.699\end{array}$ & 0.521 & 0.844 \\
\hline
\end{tabular}


International Journal of Entrepreneurship, Business and Creative Economy (IJEBCE), Vol. 1 (1), 1-12 Entrepreneurial Intention Among the University Students: Personality Traits that Matter Cheah Chew Sze, Yeow Jian Ai, Yeo Sook Fern, Yeap Jomay

\begin{tabular}{|c|c|c|c|c|}
\hline & nAch3 & 0.722 & & \\
\hline & nAch 4 & 0.687 & & \\
\hline & nAch5 & 0.806 & & \\
\hline \multirow[t]{5}{*}{ Locus of Control } & LOC1 & 0.677 & 0.516 & 0.841 \\
\hline & LOC2 & 0.621 & & \\
\hline & LOC3 & 0.763 & & \\
\hline & LOC4 & 0.734 & & \\
\hline & LOC5 & 0.784 & & \\
\hline \multirow[t]{5}{*}{ Tolerance for Risk } & ToR1 & 0.779 & 0.604 & 0.884 \\
\hline & ToR2 & 0.769 & & \\
\hline & ToR3 & 0.799 & & \\
\hline & ToR4 & 0.732 & & \\
\hline & ToR5 & 0.803 & & \\
\hline
\end{tabular}

In order to determine the discriminant validity of the constructs, Henseler et al. (2015) suggested a method that would be the Heterotrait-Monotrait Ratio (HTMT) of correlations based on a multi traits- multimethod matrix. While the discriminant validity has an issue where the HTMT value is higher than the HTMT0.90 value of 0.90 (Gold et al., 2001) and the HTMT0.85 (Kline, 2011), all values seen in Table 2 were smaller than the suggested value of 0.85 , suggesting that the discriminant validity was established. In addition, not all the confidence intervals of the HTMT values included value 1 in the range of intervals, are assured that the constructs are empirically distinct (Henseler et al.,2015). In conclusion, the study's measurement model showed adequate convergence and discriminant validity.

Table 2: Discriminant validity of constructs

\begin{tabular}{l|l|l|l|l|l}
\hline Constructs & $\mathbf{1}$ & $\mathbf{2}$ & $\mathbf{3}$ & $\mathbf{4}$ & $\mathbf{5}$ \\
\hline 1.Entrepreneurial Intention & & & & & \\
\cline { 2 - 7 } $\begin{array}{l}\text { 2.Locus of Control } \\
\text { 3.Need for Achievement }\end{array}$ & 0.692 & & & & \\
\cline { 2 - 7 } $\begin{array}{l}\text { 4.Self Efficacy } \\
\text { 5.Tolerance for Risk }\end{array}$ & 0.664 & 0.831 & & & \\
\cline { 2 - 7 } & 0.657 & 0.733 & 0.727 & & \\
\cline { 2 - 7 } & 0.807 & 0.753 & 0.720 & 0.701 & \\
\hline
\end{tabular}


International Journal of Entrepreneurship, Business and Creative Economy (IJEBCE), Vol. 1 (1), 1-12 Entrepreneurial Intention Among the University Students: Personality Traits that Matter Cheah Chew Sze, Yeow Jian Ai, Yeo Sook Fern, Yeap Jomay

\section{Structural Model Assessment}

Table 3 summarises the outcome analysis of the structural model hypothesis. The significance of the path coefficients is used to decide to support hypotheses. The result showed that among the four direct relationships, self-efficacy $(\beta=0.181, t=2.819, p<0.01)$, locus of control $(\beta=0.148$, $t=1.850, p<0.05)$, and tolerance for risk $(\beta=0.453, t=6.569, p<0.01)$ were found to have a significant influence on entrepreneurial intent among university students. Thus, $\mathrm{H} 1, \mathrm{H} 3$, and $\mathrm{H} 4$ are supported. The R2 value of the entrepreneurial intention was 0.57 , suggesting that its predictors account for $57 \%$ of the variance in the entrepreneurial intention. The effect was obtained by a modest degree of explanatory capacity ( $>0.33$ ) as recommended by Chin (1998).

Table 3: Results of the structural model

\begin{tabular}{|c|c|c|c|c|c|c|c|c|}
\hline & Std Beta & Std Error & $\overline{t \text {-value }}$ & $\overline{p \text {-value }}$ & Decision & $R 2$ & $f 2$ & VIF \\
\hline H1: SE -> EI & 0.181 & 0.064 & 2.819 & 0.002 & Support & 0.57 & 0.0395 & 1.939 \\
\hline H2: nAch $->$ EI & 0.091 & 0.072 & 1.276 & 0.101 & Reject & & 0.0096 & 2.017 \\
\hline H3: LOC -> EI & 0.148 & 0.080 & 1.850 & 0.032 & Support & & 0.0233 & 2.191 \\
\hline H4: ToR -> EI & 0.453 & 0.069 & 6.569 & 0.000 & Support & & 0.2433 & 1.967 \\
\hline
\end{tabular}

In this study, three out of four personality traits on entrepreneurship are supported while the need for achievement is rejected. The findings revealed that self-efficacy, locus of control, and tolerance for risk are significantly influenced the university students' intention in becoming an entrepreneur. These results are consistent with previous studies such as Farrukh et al., (2017); Karlsson and Moberg (2013); Santos and Liguori (2020); Karabulut (2016); Tentama \& Abdussalam, 2020. Among all the predictors, tolenrance for risk appeared to be the most influential predictor to students' entrepreneurial intention. Gurol \& Atsan (2006) has said that entrepreneurship is always associated with risk-taking. It has also been proven by Steward and Roth (2001) that entrepreneurs have a higher tolerance for risk as compared to others. One of the potential reasons that the need for achievement did not foster entrepreneurial intention is need for achievement may have an indirect effect instead of a direct effect on entrepreneurial intention. Sesen (2013) also reported that the need for achievement did not influence the entrepreneurial intention among university students in Saudi.

\section{CONCLUSION}

It is important for a university to provide students with advice and guidance for businesses. Most of the students in Malaysia are motivated, and that they have the desire to be boss of their own. However, there are some barriers that are facing by the students. The students are not equipped sufficiently with the necessary business knowledge, and that they lack experience in terms of conducting a business. An entrepreneur is not born; they can be made. This research urged the university to organized more talk series from a successful local entrepreneur and more business case-related competitions or showcases to improve student's self-efficacy and confidence. By doing so, the students have the opportunity to learn and fulfill their dream. 
International Journal of Entrepreneurship, Business and Creative Economy (IJEBCE), Vol. 1 (1), 1-12 Entrepreneurial Intention Among the University Students: Personality Traits that Matter Cheah Chew Sze, Yeow Jian Ai, Yeo Sook Fern, Yeap Jomay

Entrepreneurs are one of the sources of employment and can contribute to decreasing the unemployment rate of a country. This is why the government should introduce policies to support and encourage entrepreneurship. The government should support in terms of financial supports through deductible tax and education scholarship to promote entrepreneurship. Furthermore, the government should also fully sponsor training programs and entrepreneurial education for residents of the country so that they can be equipped with the necessary knowledge, skill, and abilities to be an entrepreneur.

There were several limitations to this study. Firstly, the sample size of data collected from the university was only 200, which is not sufficient to represent the whole population of Malaysia. In the future, the sampling size could be increased and cover more university students from a public university and a private university. Besides that, more predictors to be added in future studies such as the need for affiliation, need for power, entrepreneurial education, and innovation. Demographic information such as ethnicity and gender could also be considered in influencing entrepreneurial intention. Lastly, in order to reduce self-report bias, there are some methods besides surveys that can be employed to collect data, such as interviews, focus groups, or observation.

\section{REFERENCES}

Asante, E. A., \& Affum-Osei, E. (2019). Entrepreneurship as a career choice: The impact of locus of control on aspiring entrepreneurs' opportunity recognition. Journal of Business Research, 98, 227-235.

Ashford, J. B., and C. W. LeCroy. "Human behavior in the social environment: A multidimensional perspective . Belmont, CA: Wadsworth, Cengage Learning." (2010).

Bagozzi, R. P., \& Yi, Y. (1988). On the evaluation of structural equation models. Journal of the academy of marketing science, 16(1), 74-94.

Bandura, A. (1997). Self-efficacy and health behaviour. Cambridge handbook of psychology, health and medicine, 160-162.

Bandura, A. (2005). The primacy of self-regulation in health promotion. Applied Psychology, 54(2), 245-254.

Bandura, A. (2010). Self-efficacy. The Corsini encyclopedia of psychology, 1-3.

Brockhaus, R. H. (1980, August). Psychological and Environmental Factors Which Distinguish the Successful from the Unsuccessful Entrepreneur: A Longitudinal Study. In Academy of Management Proceedings (Vol. 1980, No. 1, pp. 368-372). Briarcliff Manor, NY 10510: Academy of Management.

Chigunta, F. J. (2002). Youth entrepreneurship: Meeting the key policy challenges (pp. 1-34).

Education Development Center.

Cromie, S. (2000). Assessing entrepreneurial inclinations: Some approaches and empirical evidence. European journal of work and organizational psychology, 9(1), 7-30.

Darren, L., \& Conrad, L. (2009). Entrepreneurship and small business management in the hospitality industry. Jordan Hill, UK: Elsevier Linacre House.

Diaz, F. (2003). Locus of control, nAch and values of community entrepreneurs. Social Behavior and Personality: an international journal, 31(8), 739-747.

Etikan, I., Musa, S. A., \& Alkassim, R. S. (2016). Comparison of convenience sampling and purposive sampling. American Journal of Theoretical and Applied Statistics, 5(1), 1-4. 
International Journal of Entrepreneurship, Business and Creative Economy (IJEBCE), Vol. 1 (1), 1-12 Entrepreneurial Intention Among the University Students: Personality Traits that Matter Cheah Chew Sze, Yeow Jian Ai, Yeo Sook Fern, Yeap Jomay

Farrukh, M., Khan, A. A., Khan, M. S., Ramzani, S. R., \& Soladoye, B. S. A. (2017). Entrepreneurial intentions: the role of family factors, personality traits, and self-efficacy. World Journal of Entrepreneurship, Management and Sustainable Development.

Gatewood, E. J., Shaver, K. G., \& Gartner, W. B. (1995). A longitudinal study of cognitive factors influencing start-up behaviors and success at venture creation. Journal of business venturing, 10(5), 371- 391.

Gilmartin, S. K., Thompson, M. E., Morton, E., Jin, Q., Chen, H. L., Colby, A., \& Sheppard, S. D. (2019). Entrepreneurial intent of engineering and business undergraduate students. Journal of Engineering Education, 108(3), 316-336.

Gold, A. H., Malhotra, A., \& Segars, A. H. (2001). Knowledge management: An organizational capabilities perspective. Journal of Management Information Systems, 18(1), 185-214.

Guerrero, M., Rialp, J., \& Urbano, D. (2008). The impact of desirability and feasibility on entrepreneurial intentions: A structural equation model. International Entrepreneurship and Management Journal, 4(1), 35-50.

Gürol, Y., \& Atsan, N. (2006). Entrepreneurial characteristics amongst university students. Education+ training.

Hair Jr, J. F., Sarstedt, M., Hopkins, L., \& Kuppelwieser, V. G. (2014). Partial least squares structural equation modeling (PLS-SEM). European business review.

Hair Jr, J. F., Sarstedt, M., Ringle, C. M., \& Gudergan, S. P. (2017). Advanced Issues in Partial Least Squares Structural Equation Modeling. SAGE Publications.

Hanapi, Z., \& Nordin, M. S. (2014). Unemployment among Malaysia graduates: graduates' attributes, lecturers' competency and quality of education. Procedia-Social and Behavioral Sciences, 112, 1056-1063.

Harris, M., \& Gibson, S. (2008). An examination of the entrepreneurial attitudes of US versus Chinese students. American Journal of Entrepreneurship, 1(1), 1.

Henseler, J., Ringle, C. M., \& Sarstedt, M. (2015). A new criterion for assessing discriminant validity in variance-based structural equation modeling. Journal of the academy of marketing science, 43(1), 115- 135.

Hisrich, R. D., Peters, M. P., \& Shepherd, D. A. (2002). Entrepreneurship, McGraw-Hill. New York.

Hsiung, T. (2018). Satisfaction with entrepreneurial education and entrepreneurial intention: The moderating role of internal locus of control. International Journal of Education and Research, 6(4), 139- 146.

Jaafar, M., Abdul-Aziz, A. R., \& Ali, R. (2009). Entrepreneurial characteristics of indigenous housing developers: The case of Malaysia. Economia. Seria Management, 12(2), 73-91. Journal of Social Psychology, 137 (1), 55-62.

Karabulut, A. T. (2016). Personality traits on entrepreneurial intention. Procedia-Social and Behavioral Sciences, 229, 12-21.

Karlsson, T., \& Moberg, K. (2013). Improving perceived entrepreneurial abilities through education: Exploratory testing of an entrepreneurial self efficacy scale in a pre-post setting. International Journal of Management Education, 11(1), 1-11.

Kazmi, S.Z.A, Uddin, S.\& Nabradi, A. (2017). What differentiates the entrepreneurs from nonentrepreneurs on nature and nurture?. Applied Studies in Agribusiness and Commerce. 11. 
International Journal of Entrepreneurship, Business and Creative Economy (IJEBCE), Vol. 1 (1), 1-12 Entrepreneurial Intention Among the University Students: Personality Traits that Matter Cheah Chew Sze, Yeow Jian Ai, Yeo Sook Fern, Yeap Jomay

Kline, R. B. (2015). Principles and practice of structural equation modeling. Guilford publications.

Koh, H. C. (1996). Testing hypotheses of entrepreneurial characteristics: A study of Hong Kong MBA students. Journal of Managerial Psychology, 11(3), 12-25.

Koudstaal, M., Sloof, R., \& Van Praag, M. (2016). Risk, uncertainty, and entrepreneurship: Evidence from a lab-in-the-field experiment. Management Science, 62(10), 2897-2915.

Kozubíková, L., Dvorský, J., Cepel, M., \& Balcerzak, A. P. (2017). Important characteristics of an entrepreneur in relation to risk-taking: Czech Republic case study. Journal of International Studies.

Kritikos, A. S. (2014). Entrepreneurs and their impact on jobs and economic growth. IZA World of Labor.

Lowden, K., Hall, S., Elliot, D., \& Lewin, J. (2011). Employers' perceptions of the employability skills of new graduates. London: Edge Foundation.

Lucky, E. O. I. (2012). Is Small and Medium Enterprise (SME) an Entrepreneurship?. International Journal of Academic Research in Business and Social Sciences, 2(1), 2222-6990.

Lunenburg, F. C. (2011). Self-efficacy in the workplace: Implications for motivation and performance. International journal of management, business, and administration, 14(1), 1-6.

Maharani, D. F., Indrawati, A., \& Saraswati, T. T. (2020). The Influence of Adversity Quotient, Need for Achievement, and Entrepreneurial Attitude on Entrepreneurial Intentions. Jurnal Entrepreneur dan Entrepreneurship, 9(1), 9-16.

McClelland, D. C. (1961). Achieving society (No. 15). Simon and Schuster.

McClelland, D. C. (1965). N achievement and entrepreneurship: A longitudinal study. Journal of Personality and Social Psychology, 1(4), 389.

Mitton, D. G. (1989). The compleat entrepreneur. Entrepreneurship Theory and Practice, 13(3), 920.

Musa, B. M., \& Semasinghe, D. M. (2013). Entrepreneurship and unemployment: A literature review. In International Conference on Business \& Information (p. 2).

Nabi, G., Holden, R., Walmsley, A., Harte, V., Jameson, S., Kyriakidou, N., \& Price, A. (2006). Careermaking: Graduating into Self-employment. National Council for Graduate Entrepreneurship, Birmingham.

Nasip, S., Amirul, S. R., Sondoh Jr, S. L., \& Tanakinjal, G. H. (2017). Psychological characteristics and entrepreneurial intention. Education+ Training.

Narathiwat, S.S., Singh., R. and Singh, B. (1997), The effect of need of achievement on attributional style

Nevid, J. S. (2012). Psychology: Concepts and applications. Nelson Education.

Prakash, D., Jain, S., \& Chauhan, K. (2015). Supportive government policies, locus of control and student's entrepreneurial intensity: a study of India. Journal of Global Entrepreneurship Research, 5(1), 26.

Riswanto, A. (2016, August). The Role of the Entrepreneur in Innovation and in Economic Development. In 2016 Global Conference on Business, Management and Entrepreneurship. 
International Journal of Entrepreneurship, Business and Creative Economy (IJEBCE), Vol. 1 (1), 1-12 Entrepreneurial Intention Among the University Students: Personality Traits that Matter Cheah Chew Sze, Yeow Jian Ai, Yeo Sook Fern, Yeap Jomay

Atlantis Press. Rosique-Blasco, M., Madrid-Guijarro, A., \& García-Pérez-de-Lema, D. (2018). The effects of personal abilities and self-efficacy on entrepreneurial intentions. International Entrepreneurship and Management Journal, 14(4), 1025-1052.

Rotter, J. (2004). Locus of control. Cognitive Approach Wrap Up Begin Emotions and Personality.

Lecture notes Psych A, 305.

Salleh, F., \& Ibrahim, M. D. (2011). Demographic characteristics differences of risk-taking propensity among micro and small business owners in Malaysia. International Journal of Business and Social Science, 2(9).

Santos, S. C., \& Liguori, E. W. (2020). Entrepreneurial self-efficacy and intentions: Outcome expectations as mediator and subjective norms as moderator. International Journal of Entrepreneurial Behaviour and Research, 26(3), 400-415.

Sesen, H. (2013). Personality or environment? A comprehensive study on the entrepreneurial intentions of university students. Education+ Training.

Sexton, D. L., \& Bowman, N. (1985). The entrepreneur: A capable executive and more. Journal of business venturing, 1(1), 129-140.

Tentama, F., \& Abdussalam, F. (2020). Internal locus of control and entrepreneurial intention: A study on vocational high school students. Journal of Education and Learning (EduLearn), 14(1), 97-102.

Thomas, A. S., \& Mueller, S. L. (2000). A case for comparative entrepreneurship: Assessing the relevance of culture. Journal of international business studies, 31(2), 287-301.

Vamvaka, V., Stoforos, C., Palaskas, T., \& Botsaris, C. (2020). Attitude toward entrepreneurship, perceived behavioral control, and entrepreneurial intention: dimensionality, structural relationships, and gender differences. Journal of Innovation and Entrepreneurship, 9(1), 5.

Van der Kuip, I., \& Verheul, I. (2003). Early development of entrepreneurial qualities: the role of initial education (No. N200311). EIM Business and Policy Research.

Wilson, F., Kickul, J., \& Marlino, D. (2007). Gender, entrepreneurial self-efficacy, and entrepreneurial career intentions: Implications for entrepreneurship education. Entrepreneurship theory and practice, 31(3), 387-406.

Yukongdi, V., \& Lopa, N. Z. (2017). Entrepreneurial intention: a study of individual, situational and gender differences. Journal of Small Business and Enterprise Development.

Zeffane, R. (2013). Need for achievement, personality and entrepreneurial potential: A study of young adults in the united Arab emirates. Journal of Enterprising Culture. 21.

Zulkosky, K. (2009). Self-Efficacy: A Concept Analysis. Nursing Forum. 44.93 - 102. 